IRISH STUDIES IN SPAIN - 2007

\title{
Reviews by
}

\author{
José Francisco Fernández
}

Copyright (c) 2008 by José Francisco Fernández. This text may be archived and redistributed both in electronic form and in hard copy, provided that the authors and journal are properly cited and no fee is charged for access.

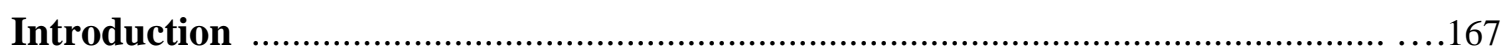

La capital de las ruinas; seguido de F- by Samuel Beckett (2007)

Federico Corriente, Iñigo García Ureta, Cristina Járboles and

Miguel Martínez-Lage, trads. 168

La literatura irlandesa en España (2007)

Antonio Raúl de Toro Santos

British and Irish Writers in the Spanish Periodical Press. Escritores británicos

e irlandeses en la prensa periódica española. 1900-1965 (2007)

Antonio Raúl de Toro Santos and David Clark

Estudios Joyceanos en Gran Canaria: Joyce “In His Palms” (2007)

Henríquez, Santiago J. y Carmen Martín Santana, coords.

The Doing of Telling on the Irish Stage. A Study of Language Performativity in

Modern and Contemporary Irish Theatre (2008)

Rosana Herrero Martín

Análisis de género en los estudios irlandeses (2007)

$\mathrm{M}^{\mathrm{a}}$ Elena Jaime de Pablos, ed.

Tentativas sobre Beckett (2007)

Julián Jiménez Heffernan, ed.

Postcolonial and Gender Perspectives in Irish Studies (2007)

Marisol Morales Ladrón, ed.

El tercer policía by Flann O’Brien (2006)

Héctor Arnau, trad.

Crónica de Dalkey byFlann O’Brien (2007)

$\mathrm{M}^{\mathrm{a}}$ José Chuliá García, trad.

Los cuatro elementos y Seamus Heaney: de la cosmogonía helénica a la cosmopoética de The Spirit Level (1996). 2007

Juan Ráez Padilla

A Provisional Dictator. James Stephens and the Fenian Movement (2007)

Marta Ramón 180

ISSN 1699-311X 
Literatura irlandesa (2007)

Beatriz Villacañas

Eavan Boland's Evolution as an Irish Woman Poet. An Outsider Within

an Outsider's Culture (2007)

Pilar Villar-Argáiz

\section{Introduction}

José Francisco Fernández, March 2008

In his preface to Modern Irish Short Stories (London: Michae1 Joseph, 1981) Anthony Burgess wrote: "Any man, whatever his nationality, has a right to admire and to propagandize for Irish literature, but it helps if he possesses Irish blood or a mad capacity for empathizing with Ireland". Although the gender exclusivity he assigns for the taste of things Irish would today be quite objectionable, I agree with Burgess's opinion. Having no Irish blood in my ancestors as far as I know, mine must be the second case, and it is true that Ireland keeps appearing in many of the things one reads.

It rang true while reading the complete and brave study Los brigadistas de habla inglesa y la guerra civil española, by Antonio R. Celada, Manuel González de la Aleja and Daniel Pastor García (Salamanca: Almar, 2006), where they include a chapter on the "Connolly Column" . By the time the Irish Parliament passed a bill in February 1937 forbidding any citizen to go to the Spanish war, many Irish volunteers were already in Spain fighting against Fascism. Around 170 men joined the ranks of the International Brigades and were destined to the Lincoln Brigade (North-American) or to the Mac-Paps (Canadian). Amongst the Irish who came to help the legitimate Spanish government there were workers, unemployed and members of the Irish Communist Party, who mainly came from Dublin, Cork, Waterford and Belfast. As well as being led by ideals of justice and solidarity, many of them made the long and difficult journey to the south of Europe to make up for the support to Franco given by General Eoin O’Duffy. For them, O'Duffy's particular crusade blemished Ireland's name.

The Irish brigadists had a distinguished role in the Battle of Jarama and later in Brunete and Ebro. Around 30 per cent of the Irish contingent died at the front. Celada, González de la Aleja and Pastor García include in their book the short biographies of Charles Donnelly, poet, Thomas O'Brien, poet and playwright, and Frank Ryan, left-wing activist and charismatic leader of the main group of Irish brigadists.

By happy coincidence, I later had the opportunity to know more about Eoin O'Duffy when Las brigadas internacionales de Franco, by Christopher Othen (Barcelona: Destino, 2007) came to my hands. Othen recounts the amazing story of this alcoholic general, admirer of Mussolini, who managed to gather a group of 700 volunteers, the Blueshirts Brigade, to "defend Spanish Catholics" but whose secret ambition was to return in triumph from the war and recover his lost influence in Ireland's national politics (he had founded the National Corporate Party in 1934 with the intention of promoting a Fascist revolution in Ireland).

Most of the young men who accompanied O'Duffy hailed from the South West of Ireland and were driven by religious (the church in Ireland supported Franco's revolt), and not political motives. They constituted the $15^{\text {th }}$ flag of the Spanish Foreign Legion, but had barely any experience of actual fighting during their time in Spain. After a brief and uninspiring contact with open fire, O'Duffy's group of volunteers were destined to defensive and secure positions, where they grew restless and disillusioned with their leader. In June 1937 they were sent back to Ireland.

How many stories, I wonder, are still to be discovered which connect Ireland and Spain? I hope that the books reviewed below (you guys 
have worked hard this year, I must say) may foster fruitful research on bright and dark areas of our common history. This is what happens after reading good books. One feels fortified for whatever trials may come one's way in the form of printed letters.

PS-1. A fellow-researcher's complaint: Why must many young scholars pay a "subsidy" to certain publishing houses to get their books published? Is it not enough that they have spent many hours of their youth locked in libraries working hard on their first publication?

PS-2. A reviewer's complaint: Why do not scholarly books published in Spain have a glossary of authors and topics in alphabetical order in the final pages? It does really help the work of consultation and it does not take much trouble to make. You have already written the book, which is the difficult part.

Beckett, Samuel. 2007. La capital de las ruinas; seguido de F-. Federico Corriente, Iñigo García Ureta, Cristina Járboles and Miguel Martínez-Lage, trads. Segovia: La Uña Rota. ISBN: 978-84-95291-11-0.

In the past six years Carlos Rod has made a commendable effort to disclose a series of Beckett's forgotten texts from his small but gallant publishing house La Uña Rota. Counting on the invaluable help of translator and Beckett enthusiast Miguel Martínez-Lage, he has so far commissioned the translations of minor but relevant works of the Beckett canon which had not been translated into Spanish or which needed new polished-up versions, and has published them in bilingual editions. These texts have been normally accompanied by Martínez-Lage's explanatory notes which have greatly enhanced the understanding of the Nobel Prize winner's lost and almost forgotten pieces.

In 2002 Carlos Rod published MartínezLage's translation of Samuel Beckett's translation of Robert Pinget's radiophonic play The Old Tune (La vieja canción). It was followed by Martínez-Lage's accomplished version of Stirrings Still (A vueltas quietas) in 2004, and in the same year he issued in one volume Beckett's abandoned play on Samuel Johnson Human Wishes (Deseos del hombre) and the seminal text usually known as the German Letter of 1937 (Carta alemana), where Martínez-Lage coined the celebrated expression of "literatura del despalabro" ("Literatur des Unworts" in the original transcript) meant to refer to that kind of writing which is aware of its own impossibility, that is, pure Beckett.

In La capital de las ruinas; seguido de F- Rod presents a translation into Spanish of different texts whose main characteristic is the fact of having been written before Samuel Beckett's intensive creative period (1947-1951) which would produce Godot, the trilogy and Texts for Nothing. The article "The Capital of Ruins", the poem "Antipepsis" and the short narrative piece "F-" had not been published before in Spanish, while the poems "Saint-Lô" and "Mort de A.D." are presented in new versions. "The Capital of Ruins" is a text written for the radio but never broadcast in which Beckett describes the function of the Irish Hospital in Saint-Lô, a heavily-bombed city in the Northern coast of France where the Irish Red Cross set up a basic but much needed infirmary just after the Second World War. Beckett worked there in the second half of 1945 as a translator, ambulance driver and handyman, as it was the only way to return to France because of the difficulties imposed on immigrants by the French government after the conflict. Among factual descriptions of the devastated environment in "La capital de las ruinas”, translated by Martínez-Lage, there are reflections on giving and receiving, on memory, returning and humanity "in ruins". "Saint-Lô", by the same translator, is a very short poem on the ghostly city and "Muerte de A.D.", in Federico Corriente's and Cristina Járboles's version, is a lament for Arthur Darley's death, a doctor in the Irish hospital who stroke up a friendship with Beckett. Íñigo García Ureta offers in "Indigestión" two competent and spirited versions of Beckett's poem "Antipepsis", and finally Martínez-Lage translates a curious piece of fiction, "F-", published by Suzanne Dumesnil (Beckett's companion for life) in the avant-garde journal transition in 1949 but commonly attributed to Beckett himself because of its bleak landscape, its oppressive atmosphere and its clumsy but inquisitive characters. 
de Toro Santos, Antonio Raúl. 2007. La literatura irlandesa en España. Coruña: Netbiblo. ISBN: 978-84-9745-216-8.

de Toro Santos, Antonio Raúl and David Clark. 2007. British and Irish Writers in the Spanish Periodical Press. Escritores británicos $e$ irlandeses en la prensa periódica española. 1900-1965. Coruña: Netbiblo. ISBN: 978-09729892-7-5.

The University Institute of Research in Irish Studies Amergin has added two new titles to its scholarly collection. In the first one, $L a$ literatura irlandesa en España, Antonio Raúl de Toro Santos presents the full text of the lecture that he gave at the James Joyce Conference in Las Palmas in 2006 (see Joyce In His Palms below). For that occasion he wrote the chronicle of the reception of Irish literature in Spain until 1965 but warned that in order to obtain a complete vision the periodical press (including literary journals and cultural magazines) had to be taken into account. This section is included now in La literatura irlandesa en España, a comprehensive research that is bound to become a manual of compulsory reference for students and teachers working in the field.

The first conclusion that de Toro Santos arrives at is that there was an almost complete ignorance on Irish writers in Spanish newspapers from 1900 to 1965, with the exceptions of Shaw, Wilde, Yeats, Swift, Goldsmith and Joyce. Sometimes authoritative voices wrote against a rush of translations of a poor quality and others complained that not many Spanish writers had destined their efforts to the act of translating. Only a few writers, de Toro Santos says, did some work of this kind, like Pedro Salinas with Proust, Ricardo Baeza with Wilde, Dámaso Alonso with Joyce and Juan Ramón Jiménez with Synge.

Juan Ramón Jiménez emerges, in fact, as a major champion of foreign literature at the time. His vast knowledge of contemporary European and American writing singled him out within the group of Spanish intellectuals. He even maintained correspondence with Yeats on the publication of his poems into Spanish. But there was low awareness of Irish literature at the time because there was, in general, little knowledge of foreign literature.

All the articles in the periodical press in which an Irish author is mentioned are included in the extensive footnotes of the book. In many cases these were reviews of published translations, like Juan Ramón Jiménez's version of Riders to the Sea by Synge. Antonio Marichalar also wrote on Liam O'Flaherty concerning the Spanish translation of The Informer. De Toro Santos does not forget to register the references to Irish literature published in the periodical press written in Galician, Basque or Catalan. Yeats's Cathleen Ní Houlihan was translated into these three languages and it was widely reviewed in the literary journals of the time. A special attention is given to Joyce in Spain, and here de Toro Santos continues the excellent tradition of research on this field which includes such works as La recepción de James Joyce en España a través de la prensa 1920-1975 (1997) by Carlos García Santacecilia; Joyce en España I (1994) and Joyce en España II (1997) by García Tortosa and de Toro Santos, and James Joyce in Spain. A Critical Bibliography (1972-2002) (2003) by Lázaro and de Toro Santos.

A second essay in the book considers the response that Irish writers had in other peninsular languages. De Toro Santos focuses on the privileged relation between Galician and Irish literature, tackling such themes as commercial, religious and military events that connected both communities along history.

Since the mid- $19^{\text {th }}$ century, it has been revealed, Galician intellectuals were sympathetic to the Irish for their fight against the English. For the regionalist and nationalist movements that rose in that century in Galicia, the Basque Country and Catalonia, Ireland appeared as a model and took the role of a sister nation. But only in Galicia, de Toro Santos explains, this interest extended to Irish literature, perhaps due to common Celtic roots.

It is necessary to note at this point the fundamental role in the promotion of Irish literature by the journal Nós, which ran from 1920 to 1936. Key intellectuals such as Vicente Risco, Ramón Otero Pedrayo or Plácido Ramón Castro stimulated the study of Irish literature to an extent that was unmatched in the rest of Spain. Otero Pedrayo translated fragments of Ulysses into Galician in 1926 and Risco wrote Dedalus in Compostela (1929), an early fictional account of a Joycean character in an European 
language. Yeats also found a relevant niche in the journal Nós. The Galician translation of Cathleen Ní Houlihan, by A. Villar Ponte, was published there in 1921. Galician intellectuals found in Irish literature a mirror in which they wanted to see their own image, and frequently looked at Irish shores looking for inspiration and models of their own literature, as Plácido Ramón Castro imagined Galician theatre based on standards set by Ireland. The book is complemented by an appendix with all the literary works by Irish writers published until 1965 that can be found in the National Library in Madrid.

British and Irish Writers in the Spanish Periodical Press 1900-1965 by de Toro Santos and David Clark is an instructed and extensivelydocumented work of reference which contains a detailed record of every article published in Spain on Irish and British authors during the time in question. One can hardly imagine the various years of work that such a volume has taken the authors. It implied the consultation in different libraries and the task of going through dozens of journals, newspapers and weekly publications page by page. In its dictionary-like format, it offers a complete vision of the reception of English and Irish writers in Spain for more than half a century. It also contains useful appendixes of English literature in Spain, of translation and of historical and cultural references to Ireland in those publications. The present reviewer fervently encourages the authors to continue their work with a future volume that would comprise the period of the last forty years.

Henríquez, Santiago J. y Carmen Martín Santana, coords. 2007. Estudios Joyceanos en Gran Canaria: Joyce "In His Palms". Madrid: Huerga y Fierro. ISBN: 978-84-8374-677-6.

The first translation of James Joyce's Ulysses into Catalan was made by Joaquim Mallafrè in 1981. Or was it? There exists a previous unpublished version of Joyce's masterpiece which bears the date of 1966 and lies in a box at the General Archives of the Spanish Administration in Alcalá de Henares. This felicitous discovery was made by Alberto Lázaro and a fascinating account of the genesis of this unknown document is provided in the book of proceedings of the $17^{\text {th }}$ annual meeting of the Spanish James Joyce Association, which took place in Las Palmas de Gran Canaria on 19-22 April 2006.

Alberto Lázaro's article is dedicated to answer the obvious questions concerning the mysterious translation: Who wrote it? Whose initiative was it? Why was it never published? Joan Francesc Vidal Jové is hence rescued from oblivion in an exemplary work of research, based on a diligent reconstruction of events which took Lázaro on a journey to different archives and libraries, and also counted on the help offered by the translator's daughter. Vidal Jové was a politically-involved man of letters who had to go into exile at the beginning of the Civil War. He later returned to Spain and carried out an intense literary activity in the 1950s and 60s as a writer, editor and translator from French and Catalan into Spanish. He translated Ulysses into Catalan from Auguste Morel's French version and sent the result to his son-in-law George Cheyne, a scholar at Newcastle University, who would revise and compare Vidal Jové's text with the original in English. According to Alberto Lázaro, Vidal Jové showed a vivid imagination and a discerning intellect in his rendering of Joyce's novel. Details of the enigmatic publishing house which accepted the manuscript, AHR, are also generously given, as well as a likely explanation of why the book was not finally published. This is, in short, a rare and extraordinary discovery that must be described in glowing terms.

This serves to prove that despite the general misconception over books of proceedings, sometimes little gems can be found in these apparently cursory volumes. Alberto Lázaro's article is one of them, but the present book abounds in remarkable pieces of criticism. José Miguel Alonso Giráldez writes wisely on the language of frustration in Ulysses. He explores the author's personal nightmares that might have resulted in the novel's broken syntax, unfinished sentences and stylistic complexity. Alonso Giráldez delves into the unfulfilled sexuality (voyeurism, masochism, onanism) of the main characters to shed light on the most disturbing features of Joyce's novel.

Antonio Raúl de Toro Santos is one of the contributors to Joyce In His Palms who also reveals some unknown facts. In his agreeable 
discussion on Irish literature in Spain in the first half of the $20^{\text {th }}$ century he expands on the reception of writers from the Irish Literary Revival by renown Spanish authors such as Juan Ramón Jiménez or Federico García Lorca. There was, de Toro Santos states, a marked affinity in Irish and Spanish writers with regards to their interest in indigenous peripheral culture in their countries. Juan Ramón Jiménez translated Irish authors such as Synge, AE and Yeats. He recommended Valle-Inclán's play Divinas Palabras to the director of the Abbey Theatre in Dublin, and Lorca was influenced by Jiménez's translation of Riders to the Sea. A copy of one volume of Synge's book, dedicated by Lorca to Galician poet Carlos Martínez-Barbeito is one of the discoveries made by de Toro Santos.

This article is followed by a paper by Benigno del Río, who reads the second chapter of Ulysses, "Nestor", from a multicultural perspective, having Ezra Pound's XLV Canto as a point of reference. Benigno del Río captures the colourless and deadening "still-life" quality in some scenes of the chapter caused by the negative influence of money, establishing powerful connections between the devaluation of language and the devaluation of currency.

Susana Domínguez Pena studies Sean O'Faolain's difficult relationship with his native country and his criticism towards the Catholic Church in his short stories. José Manuel Estévez Saá also sets himself the task of studying short stories, those included in the collection New Dubliners (2005), focusing on Dermot Bolger's personal homage to Ulysses in the narrative "Martha's Streets". Margarita Estévez Saá cleverly addresses the question of Lucia Joyce's influence on her father when he was writing Finnegans Wake. Carol Loeb Shloss's polemical biography of this intriguing character, Lucia Joyce. To Dance in the Wake (2004) is regarded to be biased and partial but, Margarita Estévez Saá claims, Shloss might be right in her appreciation of Lucia's complicity in the composition of her father's last book. Her presence is unmistakably detected in the book and abundant references indicate that she was part of Joyce's creative process.

Rafael García León makes use of the metaphor of the world as a stage to search for the terms used by Joyce to link life with theatrical allusions. He discusses Joyce's ideas on drama and his only incursion into the world of theatre. Francisco García Tortosa's contribution pays attention to the presence of Jews in Ulysses. There are certain points in common between the Irish writer's erratic existence and the plight of the Jewish people along the centuries. But being Ulysses, in part, a precise testimony of Dublin's social structure at the beginning of the $20^{\text {th }}$ century, it is reasonable to ask why did Joyce make one of his main characters a Jew when there were not many of them in Dublin at the time. García Tortosa's incisive erudition can be discerned throughout his explanation: in order to create the uncharted history of his country, Joyce had to immerse his fiction in the origins of Ireland, on the one hand, and on the pillars of Western civilization, on the other: Rome, Greece and Israel. García Tortosa also traces the possible origins of Leopold and Molly Bloom as part of the migratory movements of Jews from Central and Southern Europe towards the West.

María Isabel González Cruz makes a revision of the sociolinguistic aspects in Dubliners, and Santiago J. Henríquez Jiménez explores the vitality of Irish writing from the genius of Wilde, Yeats, Joyce and Beckett to the energy of modern Irish talents. Rubén Jarazo Álvarez delves into the influence of literature written in English on a paradigmatic figure in Galician letters, Álvaro Cunqueiro. Jarazo Álvarez first exposes how important Galician intellectuals, notably Vicente Risco, defined their culture in connection with other literatures of the Atlantic shores: Irish, Scottish or Welsh. Next, he introduces the work of Álvaro Cunquerio, who incorporated references from the Celtic and English literary universe into his work. Finally, the influence of Lord Dunsany's fantastic literature on the Galician writer is firmly established.

Lidia María Montero Ameneiro studies in Molly Keane's novel Two Days in Aragon (1941), the relationship between the members of the Ascendancy living in the Big House of the title with the representative figures of Catholic Ireland: their servants and an Irish rebel in the period after the Anglo-Irish war.

The rest of the articles in the volume are worthy of careful attention too: Maureen Mulligan writes on the importance of music in 
Joyce's “The Dead". Juan Ignacio Oliva examines Joycean echoes in the confessional writing of Anglo-Indian writers Amit Chaudhuri and Shyam Selvadurai. Sonia Petisco considers Molly Bloom's monologue in Ulysses from the perspective of the inner de-centering of the modern subject. María Isabel Porcel García evaluates the influence of Valery Larbaud on Joyce and Jefferey Simons carefully analyzes the stages of writing in the seventh episode of Ulysses, “Aeolus". María de la Cinta Zunino Garrido's contribution aptly puts an end to his collection of papers. She traces biblical echoes in Joyce's book of poems Chamber Music. In her view, there are many similarities between the style and imagery of the Biblical Song of Songs and Joyce's early book of verse, particularly in relation to the union of lovers. Zunino Garrido efficiently describes the Jesuit cultural background in which Joyce was brought up and provides textual evidence for the connection between the Biblical text and Joyce's poems. The resemblance between Joyce's lyrics and St. John of the Cross mystic poems is also established.

Perhaps a final note should be addressed to those responsible for the editing process at the publishing house. It is a matter of regret that such a splendid collection of articles is spoiled by a certain sloppiness: there are too many typos, a thorough revision of punctuation should be made and a systematic homogenization with regards to titles of books and bibliographic references would also be advisable.

Herrero Martín, Rosana. 2008. The Doing of Telling on the Irish Stage. A Study of Language Performativity in Modern and Contemporary Irish Theatre. Frankfurt am Main: Peter Lang. ISBN: 978-3-631-57450-8.

Many studies on contemporary literature lack a guiding principle to connect all the threads that remain unexplained and unrelated. Rosana Herrero Martín's book is a different case. From the consideration of language's performative nature she in fact builds an alternative history of contemporary Irish theatre.

Her thesis is that language has not normally been used in Irish drama for the presentation of actual facts, but has become a protagonist in itself, it has put more emphasis on telling rather than doing and it has raised imagination to the category of primal force in the scene. Her project has been the revision of Irish theatre in the past 125 years stressing this element in the major theatrical movements during this period. With the long sequence of authors and plays described in the book, The Doing of Telling on the Irish Stage is a considerable feat of orchestration.

Herrero's dissertation is divided into four parts. The first chapter presents the multidisciplinary approach of her study, consisting of a complex theoretical framework where different schools of thought are represented: speech acts theory, orality, poststructuralism, phenomenology, therapeutic approach to story telling, postcolonialism, the revisionist perspective of history and the teachings of Lacan on the unconscious. With such a combination of procedures (some of the approaches are difficult to reconcile) the book may lack a cause-and-effect uniformity, but it gains in colour, interest and freedom. All these movements and theories, nevertheless, are applied at some point in the book without neglecting the main tenet: Most Irish contemporary theatrical repertoire is antinaturalistic and non-mimetic, in other words, it is theatre of language in performance. In many of the plays studied in the following chapters English as the written word is represented with awe and mistrust. That is why the Irish stage has focused on the oral faculty of language, as a way of searching for roots in the ancient traditions of an ancient language: "As a country whose people have suffered a long history of dispossession in reality, Ireland has fervently sought its sense of identity in the imaginary" (31). The pervasive idea of language on the Irish stage as a structure with an enormous destabilising potential enables Rosana Herrero to make her way through the burning charcoal of theory unscathed.

W. B. Yeats, naturally, occupies the discussion of theatre in the next chapter. As Rosana Herrero reminds the reader, he was the first writer to formulate the role of the Irish dramatist as shaman. His linguistic idealism and his continuous use of symbols, dreams, dance, masks and reveries in his plays make him the founding figure of the non-factual theatre in Ireland. He left a legacy that other Irish dramatists have, to a bigger or lesser extent, 
followed. Herrero delves into Yeats's ritualistic procedures in theatre along the whole of his literary career, analysing early plays such as $\mathrm{On}$ Baile's Strand (1904) or mature ones such as Purgatory (1938). Herrero traces Yeats's evolution as a dramatist from his beginnings as an author who relied on language alone to arouse the imagination (he was a poet after all) to his latter attempts towards the necessary collaboration between speech and physicality. His central role in the foundation of the Abbey Theatre and his unsuccessful attempt to connect with the audience of his time is fully analysed and contextualised.

Herrero next studies five plays of the "early Irish theatre movement" that roughly coincide with Yeats's career in theatre writing: Dion Boucicault's The Shaughraun (1875), Oscar Wilde's The Importance of Being Earnest (1895), Lady Gregory's Spreading the News (1904), J. M. Synge's The Playboy of the Western World (1907) and Sean O'Casey's The Shadow of a Gunman (1923). Again, the use of language as the carrier of a renewed meaning of reality is the common factor that links such diverse plays from Boucicault's alteration of the stereotype of "the stage Irishman" to Wilde's heterodox linguistic dexterity, without leaving aside the rich linguistic texture of The Playboy of the Western World.

Samuel Beckett projects his troubled shadow in the third chapter and here Rosana Herrero shows a profound knowledge of his intellectual background. She rightly describes that the source behind Beckett's endless experimentation on stage lies on a solid intellectual basis, namely, his conception of language as a fraudulent vehicle of expression. She traces the author's evolution through apprenticeship with Joyce, his contact with the musical and visual arts, his readings of Fritz Mauthner and his abandonment of English in order to search for his own voice. The main dramatic texts of the Irish author are carefully dissected, reaching precise conclusions: "Language, in particular, storytelling, is resorted to by Beckett's characters as a therapeutic method to exorcise loneliness, existential boredom, and above all, to provide their lives with an illusion of coherent sequence" (132-3). Herrero's chapter on Beckett is formidably polished and it goes in the opposite direction from stereotypical accounts of his work.

Finally, in the fourth chapter, the plays of seven contemporary dramatists (Brian Friel, Tom Murphy, Frank McGuinnes, Sebastian Barry, Marina Carr, Donal O’Kelly and Enda Walsh) are discussed to prove that the central notion of language's performativity is kept alive in subversive and radical forms by the new generation of Irish playwrights.

Jaime de Pablos, $\mathrm{M}^{\mathrm{a}}$ Elena, ed. 2007. Análisis de género en los estudios irlandeses. Almería: Editorial Universidad de Almería. ISBN: 97884-8240-705-0.

Elena Jaime has edited a collection of articles which centre around Irish literature and culture from a gender studies perspective. This is a difficult book to speak about because I was invited to present an article and I am therefore an interested part and of course favourably biased. I will then merely expose the contents of what I consider to be relevant contributions to the stimulating field of Feminist and Gender Studies.

In the first essay María Amor Barros del Río compares the masculine bildungsroman with its feminine counterpart, the latter being a literary mode which has developed enormously in Ireland in the second half of the $20^{\text {th }}$ century. Some representative novels by Kate O'Brien, Edna O’Brien, Éilís Ní Dhuibhne, Kate Cruise and Moya Roddy are chosen by Amor Barros to show the new tendencies in the Irish bildungsroman written by women.

In the second article Silvia Díez Fabre focuses on Somerville and Ross's famous narrative The Real Charlotte (1894). Hers is an analysis of the main character of the novel, which has normally been described as a monster-woman (an immoral arriviste). However, Charlotte is also revealed as a woman who acts contrary to the passive stereotype of the Victorian "Angel in the house" and who rebels against the patriarchal structures of Irish society.

In the third chapter I write on masculinity and power in Bernard Mac Laverty's novels and in the fourth chapter Asier Altuna analyzes gender representations in the female characters of two theatre plays which evoke a Spanish atmosphere, Spanish Patriots a Thousand Years Ago (1812) by Henry Brereton Code and The Rose of Arragon (1842) by James Sheridan Knowles. 
Next, Keith Gregor makes a revision of the impact of contemporary theatre plays written by women in Northern Ireland. In the sixth chapter the editor of the volume provides a close scrutiny of Nora Glynn, a female character in George Moore's The Lake (1905), using as a theoretical frame the joined concepts of woman and nature in the dynamic sense that Moore understood them to be.

Roddy Doyle's powerful novel The Woman Who Walked into Doors (1996) is the subject of the seventh chapter, written by Marisol Morales Ladrón. The novel is a condemnation of domestic violence written in the first person by a woman who tries to put her thoughts in order and explain herself. Morales Ladrón examines Doyle's mordant satire of the institutions which allow the exertion of masculinist violence upon women.

Inés Praga Terente considers the echoes of García Lorca's La casa de Bernarda Alba (1936) in Brian Friel's Dancing at Lughnasa (1990). There are many points in common in the argument and in the historical contexts recreated in both plays, despite belonging to different cultural traditions. The representation of women locked at home and oppressed by an iron-strong sexual morality truly reflect the real experiences lived by women in Ireland and Spain for decades.

In the final chapter Patricia Trainor pays attention to the fascinating figure of Maud Gonne, the "Irish Joan of Arch", who fought all her life for the independence of Ireland with articles, lectures and in her activity with regard to Irish political prisoners. Trainor also provides an account of Gonne's troubled relationship with W. B. Yeats.

\section{Jiménez Heffernan, Julián, ed. 2007. Tentativas sobre Beckett. Madrid: Círculo de Bellas Artes. ISBN: 978-84-86418-88-5.}

As part of the centenary celebrations commemorating Samuel Beckett's birth, a cycle of lectures took place at the Círculo de Bellas Artes in Madrid on 2-4 October 2006. The book under review is comprised of the revised talks presented at that event, edited by Julián Jiménez Heffernan, senior lecturer in English at the University of Córdoba. The editor is aware of Beckett's sacralisation in recent times as an icon of modernity and acknowledges both his sense of betrayal for producing a book on his work (Beckett never fostered any interpretative quest on what he wrote) and the unavoidable failure of such endeavour. In any case, he adds in the prologue, the articles included in the present volume are just tentative approaches, part of an exploratory process of interpretation that will never be finished, that cannot be finished because the last and extemporaneous modernist will never be fully apprehended. The positive effect of volumes like this one is that readers are encouraged to go back to the texts again, looking for missed nuances and applying new perspectives to their reading. The articles in the book are highly philosophical and tread firmly through the imposing regions of theory.

Manuel Asensi Pérez, in the first contribution to the book, affirms that Beckett's difficulty stems from the author's explicit rejection of declarative statements in his work. It is as if Beckett foretold what was going to happen when the questioning gaze of critics started to pay attention to his work. The writing he produced, therefore, had the seeds of its own deconstruction and thus dismantled any attempt towards interpretation.

Asensi Pérez considers one instance of such a scheme: the abundance of the adversative conjunction but in Molloy. As is well known the novel exhibits a high degree of hiper-reflexivity: at the same time we read Molloy's story and Molloy's telling of that same story, with the ensuing impossibility of reaching clear conclusions. Molloy subverts the traditional rhetoric figure of correctio because although he goes back over his words and tries at all times to redefine what has just been said, no real correction is provided, confusing the reader (and himself) even more in the process. Rather than adjusting the lens, the narrative is de-focalized and a radical unknowingness is everything that we have finally gained.

In the second chapter Derek Attridge provides a thorough exposition of Beckett's presence on John Coetzee. The South African writer was one of the many artists who felt fascinated by the Irish master and even wrote a scientificallyinspired Ph.D. dissertation on his work in an attempt to have access to its secrets. Crucial to Coetzee's engagement with the fiction of Beckett 
is the latter's handling of the English language, the way he transforms ordinary and sometimes grim lives into an intense pleasure for the reader. What Coetzee learnt from Beckett, Attridge says, is that style is an aim in itself, not just a road towards meaning. Although the younger writer admired the comedy in Beckett's work, his novels are tinged with something close to bitter irony. Nevertheless, Coetzee was more successful in adopting for his characters the mechanical, distant, unexciting attitude towards sex that he saw in Beckett's novels.

José Manuel Cuesta Abad tries to solve a problem in the third chapter of the book. Beckett's work spins over an obsessive concept: the idea that his writing seems produced by a non-entity, the speaking subject being equivalent to no one saying things that cannot be said. If this is so, what kind of experience is worth the expression represented in the literary work? For Cuesta Abad Beckett's writing is the place where the possibility of experience is devoured by the experience of the impossible. Beckett's creatures have something of the unborn, not fully alive nor completely dead either, half beings for ever digesting continuously recited words. Beckettian characters are instances of a verbal flow: they obtain their identity from the verbosity that builds their individualization. The anti-essential humanity in his novels (symbolized by the depiction of miserable, poor, forsaken vagrants) would have as a result the unassailable quality of his writing.

Julián Jiménez Heffernan writes what I consider to be the best chapter of the book. He posits the thesis that if Beckett, as is commonly asserted, dismantled the Western tradition of narrative, he must have known it well in the first place. In any case for Jiménez Heffernan the novel as a literary genre was doomed to obliterate itself from the very beginning, it was destined to meet the end of the God-like author, a state of things that Beckett's writing perfectly symbolizes and which is widely accepted today.

Jiménez Heffernan claims that Beckett did not destroy anything and advances powerful reasons: he wrote novels (not anti-novels, Jiménez Heffernan stresses); there is plenty of evidence in the form of echoes and allusions to show that his novels are deeply embedded in the long history of novel writing (Jiménez Heffernan speaks of
Beckett's seven novels. I would say there are eight of them as Dream of Fair to Middling Women is not a mere draft but a fully completed work); this same tradition has always shown a great capacity to reshape itself and to give birth to new forms which have renewed the genre. Beckett would belong to this category of alternative writing as old as the novel itself.

This appreciation is not completely new. José Ángel García Landa in Samuel Beckett y la Narración Reflexiva (Zaragoza: Prensas Universitarias, 1992) also placed Beckett's prose fiction in the tradition of the novel. In his study on Beckett's trilogy, García Landa claimed that Beckett's subversion of the novelistic genre implied in fact the conquering of new territories for this fictional form. It must also be said, however, that the concept of anti-novel does not necessary cancel any kinship with a previous tradition. In his A Dictionary of Narratology (Lincoln: University of Nebraska Press, 1987) Gerald Prince defines antinarrative merely as "A (verbal or nonverbal) text adopting the trappings of narrative but systematically calling narrative logic and narrative conventions into question”, and he mentions Molloy as an example of antinarrative.

What is powerfully original is Jiménez Heffernan's convincing and wide-ranging explanations of the Irish writer's belonging to a pre-existing lineage. He establishes the Gospel as a primal antecedent for Beckett's narratives and proves that Fielding's classic definition of the novel as "a comic Epic-Poem in Prose" is a frame that Beckett's novels conform to. Jiménez Heffernan proposes that for a better understanding of Beckett's enigmatic work, and against ethereal interpretations, one has to keep in mind that his writing is deeply anthropomorphic: a human body (or at least part of it) is always represented. A humanistic resolution lies behind Beckett's anthropocentric interest. His work, though, would be excised of any moralistic imprint.

Beckett, Jiménez Heffernan states, had no inventiveness, there is nothing to find out or discover: he registered what was already given rather than inventing what did not exist. Hence Beckett's preference for the inventory, by means of which his characters frequently register their ridiculous possessions. A revision of Beckett's 
obsessive catalogues of things in his novels complements this excellent paper.

In the last chapter José A. Sánchez writes about scenic image and cinematographic action in Beckett. Tracing an analogy from a picture of the author, Sánchez develops the idea of how Beckett also kept control of his image in his theatre plays: he allowed remnants of his own subjectivity to reach his characters but refrained from giving them total capacity of seduction. His characters are thrown out on stage as bodies to which fragments of discourses are added. Sánchez explores Beckett's theatrical knowledge beginning with the description of Roger Blin's mythical staging of Waiting for Godot in 1953. Considerations on the physicality of some Beckettian characters are also provided. In his theatre and in his radio plays Beckett developed a kind of visually-focused writing, in the sense that he took into consideration the spectator's gaze. Willie in Happy Days is an adequate example of the way the playwright tried to control the audience's way of looking at the scene. Glances, eyes and ways of looking took an increasing importance in his plays as the weight of meaning in words was reduced, tending towards the creation of scenic objects. In this context, the 1999 project Beckett on Film, in which 19 dramatic works by Beckett were filmed by different directors, is properly assessed.

Morales Ladrón, Marisol, ed. 2007. Postcolonial and Gender Perspectives in Irish Studies. Coruña: Netbiblo. ISBN: 978-09729892-6-8.

"There is no consensus on the application of the term postcolonial to the Irish case" (xix) writes Marisol Morales Ladrón in the introduction to this book. Certainly no simple answers can be given to the status of Ireland in relation to postcolonialism. Many scholars have alluded to the special characteristics of the Republic, its "atypical case" within the context of the former colonies of the British Empire. Furthermore, a postcolonial adscription to Northern Ireland seems controversial and open to debate. It is a measure of the editor's skill that she has effectively managed to gather a series of articles by Spanish scholars in which the postcolonial approach is unambiguously advocated. The contributors to Postcolonial and
Gender Perspectives in Irish Studies believe that useful results can be obtained by applying to Irish studies the theories and views of outstanding critics of postcolonialism. The articles in this volume, divided into the general areas of "Postcolonialism, language and gender", "poetry", "fiction”, "drama” and "cinema”, also take into account the sharp perspectives that gender studies may project, so that the present book must be understood as an open field where postcolonial studies and feminist studies are seen at work in the common objective of capturing updated considerations on the literature and cinema of modern Ireland.

In the first article Isabel Carrera Suárez offers a complete panorama of the state of the question. She analyzes the consideration that the Irish case has had in postcolonial theory, from The Empire Writes Back (1989) by Ashcroft, Griffiths and Tiffin, to Inventing Ireland (1995), by Declan Kiberd. She reveals that postcolonial studies in Ireland have taken ground since the 1980s and for her it is clear that Irish Studies have widened the spectrum of postcolonial theory. Key texts which have opened the way for a plural vision of Ireland, such as The Field Day Anthology of Irish Writing (1991) edited by Seamus Deane, Anomalous States (1993) by David Lloyd or Inventing Ireland are earnestly described. These books have helped to put Ireland under the lens of postcolonialism. On the negative side of this process, Carrera Suárez writes, the contributions by feminist theorists are still neglected and have not yet been integrated into this current of thought.

In the second article of the collection Asier Altuna focuses on Gaelic and the question of how it can be considered from a postcolonial perspective. Altuna's first aim is to dive into the past and to examine the evolution of the Irish language and its relationship with power. The necessity of this task is paramount because, in Asier Altuna's words, today's politicisation of the Irish language bears a resemblance to cultural and political tensions of previous centuries (19). In his journey through the history of Gaelic the author explains that Irish was an important element in the intention of the first government after independence to gaelicise Ireland, although their initial impetus was somehow tempered with the passing of time. 
Historical events like the Great Famine of 1845 or the foundation of the Gaelic League in 1893 are viewed from the perspective of their effect on the native language of Ireland. Although many official attempts were made to preserve and to promote the language, its real use has been limited. In the postcolonial world we live in, hybridity is for Altuna a sign of strength in the context of the Irish language and he supports his views with the opinion of authors like Nuala Ní Dhomhnaill, for whom the translations from Irish are a modern and acceptable approach to this issue. "Translations" concludes Asier Altuna, "should be conceived as a significant component of a global, hybrid and multicultural Ireland" (38).

The following article, written by Manuela Palacios, focuses on the poets of Northern Ireland, who fill with their work the borderland between the two frontiers, the two different national identities and the two religions. Palacios's article is a thoughtful and stereotypebreaking piece of criticism in that she avoids any Manichean polarities regarding the North and the South: "We observe in the poetry of the North a persistent need to approach the other" (47).

She considers it problematic to analyse Northern poetry as a literary entity that is unquestionably distinct from that of the Republic, and interrogates its elusiveness. Next, she presents an overview of the different generations of Northern Ireland poets and revisits well-known poems such as Seamus Heaney's “Punishment”, Michael Longley's "Wounds" and Derek Mahon's "A Disused Shed in Co. Wexford", going beyond the mere exposition of the authors' features of style. Leaving open the debate within the articles of the book, Manuela Palacios shows a different opinion from Asier Altuna regarding translations from Gaelic. For her, it is simply a consequence of the predominance of a few global languages: "The problem I see with this is the paradoxical effect that while Gaelic declines, its related cultural products are only allowed to survive through translation" (60). Far from being a monolithic block, the articles in the book move freely around the connections between literature and postcolonialism, offering different ways to consider the question and to enliven the debate.

Luz Mar González Arias is the author of the next chapter in which love discourse is studied. Far from being an abstract universe, unaffected by the events in the world, González Arias proves that love poetry in contemporary women Irish poets is embedded in the political tug-ofwar that has shaped modern Ireland. Incomplete representations of women, constraints imposed upon their sexuality or the exploration of sensory experience are some of the topics dealt with in this examination of the work of Eavan Boland, Katie Donovan, Nuala Ní Dhomhnaill, Paula Meehan, Dorothy Molloy, Anne Hartigan and Leanne O'Sullivan.

Esther Aliaga Rodrigo's chapter plunges into the depths of the conflict in Northern Ireland through the analysis of the recent work of two novelists of different persuasion, Protestant Glenn Patterson and Catholic Robert McLiam Wilson. They represent a new generation of writers who have struggled to approach the Troubles in a non-sectarian manner, showing an eagerness to find flexible and authentic definitions which may embrace both heterogeneity and modernity.

María Amor Barros del Río also writes about novels, but this time focusing on women writers. In her chapter she studies three periods in which women novelists have tried to search for their own identity outside social and historical impositions. An ample revision is thus made from Emily Lawless's Grania (1892) to Catherine Dunne's The Walled Garden (2000).

The seventh chapter is written by Tamara Benito de la Iglesia and she claims that no event has been dealt with so extensively in Irish short stories as the Troubles. She studies selected short stories from the production of four male Irish writers whose response to the colonial rule have ranged from straight denunciation of abuses from the security forces to the presentation of violence as a dehumanizing consequence of the conflict.

Margarita Estévez Saá also takes into consideration the field of the short story. In her contribution she offers revealing insights into the works of contemporary short story women writers who have not normally found a representation in anthologies of Irish writing. Estévez Saá rejects the accusation that women writers do not dare to go beyond realistic and autobiographical modes and offers the example set by collections from the late nineties and the 
beginning of the new millennium where literary experimentation, lyric intensity and the description of modern, urban lives go hand in hand with other stories of a more traditional content.

The next chapter introduces us to the field of modern Irish theatre. María del Mar González Chacón undertakes the task of reading the work of three female playwrights from Nothern Ireland (Marie Jones, Anne Devlin and Christina Reid) using a postcolonial perspective. The career of each writer is carefully displayed and special attention is given to the Charabanc Theatre Company, created in Belfast in 1983 by five actresses who established themselves as a progressive force devoted to the representation of the experiences of women in their different communities, avoiding in their productions the re-enactment of already-formed images.

Rosana Herrero Martín complements the panoramic view of modern Irish theatre with a chapter on Tom Murphy's A Crucial Week in the Life of a Grocer's Assistant (1969) and Sebastian Barry's Boss Grady's Boys (1988). In the two plays under analysis there are representations of parental overshadowing and this is taken as a model to explore the prolonged childhood of the Irish State under De Valera's governments. Sebastian Barry's play shows an interest in giving voice to the dispossessed, while Tom Murphy's achievement is to take on stage dreams and fantasy in a period of stifling parochialism.

The final chapter of the book, written by Rosa González Casademont, also constitutes the section devoted to Irish cinema. Hers is an attentive analysis of how Ireland has been represented in cinema. González Casademont offers as well an exhaustively-documented sampling of films which have somehow attempted to capture in images the essence of Ireland. The article is divided into four sections due to an expressed intention of avoiding easy categorisations. González Casademont examines separately the filmic representation of Ireland in the US, in the UK, the characteristics of indigenous cinema, which has developed in the last two decades, and finally a whole section is devoted to the presence of Northern Ireland on screen. Many well-known films (and others which have not transcended the frontiers of the Republic) are commented upon, revealing the signifiers of Irishness that have been favoured by the different productions. Issues of gender, ethics or detailed aspects such as films in Irish are considered in this finely drawn cartography of Ireland on screen.

O’Brien, Flann. 2006. El tercer policía. Héctor Arnau, trad. Madrid: Nórdica Libros. ISBN: 84-934854-8-9.

O’Brien, Flann. 2007. Crónica de Dalkey. $\mathbf{M}^{\mathrm{a}}$ José Chuliá García, trad. Madrid: Nórdica Libros. ISBN: 978-84-935578-1-2.

Flann O’Brien is never a duff read. His literary talent is what one would get if you mixed James Joyce's linguistic virtuosity with the content of your strangest dreams and left the result in the middle of a rural Irish pub. His crazy logic has been wonderfully rendered into Spanish in these novels (published originally in English in 1967 and 1964) that Nórdica Libros has produced in the past two years.

In Beatriz Villacañas's book (see below) it can be read that O'Brien's masterpiece At SwimTwo-Birds (1939) was translated into Spanish by José Manuel Álvarez Flórez (En Nadar-DosPájaros. Barcelona: Edhasa, 1989) and she adds that it was "un acto de valentía". The editors at Nórdica Libros must be lauded therefore for having commissioned these two equally courageous translations. In both versions into Spanish, the first by Héctor Arnau and the second by $\mathrm{M}^{\mathrm{a}}$ José Chuliá García, the job is done in a very professional and efficient way. O'Brien is not a well-known writer in Spain, but with these novels available to buy readers will be able to discover and enjoy a highly subversive author.

In El tercer policía humour comes naturally with the adventures of the protagonist and his obsession with de Selby, a mad scientist who believes that objects (such as bicycles) can exchange atoms with their owners (so that they become bicycle-men). In this novel the translation is fluent and rich in nuances. The flavour and atmosphere of Irish landscapes can be imagined easily, without almost noticing the presence of an intermediary. Descriptions of fields, villages and streets are realistic but at the same time tinged with a veil of bewilderment, which gives them an almost dream-like quality.

Ireland is described by the protagonist's father as "un país rarito" (10) ("Ireland was a queer 
country" in the original) and a strange country it is indeed, where policemen discourse upon the five rules of wisdom or steal people's bicycles to prevent the intermingling of particles. De Selby's theories, interspersed in the narrative, are deliciously absurd, like his comment on roads being kind to the traveller or unkind if they go in the wrong direction.

The second book shares the same oneiric universe of the first one. This time de Selby himself is one of the main characters and it is so exultantly funny to read that he has the power to summon the dead. James Joyce turns up and denies having written Ulysses. He in fact is presented as a prudish individual who disowns that pornographic book and expresses his desire to join the Jesuits. O'Brien was simply a genius.

In Crónica de Dalkey Chuliá García makes occasional use of colloquial expressions which are adequate in the context of informal conversation: “¿Fue un lingotazo de whiskey el fundamento de este follón?” (95) (“Was a feed of whiskey the foundation of this rigmarole?" in the original), or "Me las arreglé para salir de estranjis en un pequeño carguero" (268) ("I managed to sneak across in a small freighter"). However, I object to her abundant use of translator's notes. I really think she goes too far in her attempt to make the cultural references accessible to Spanish readers. Notes should be treated in literary works like Tabasco sauce: it must be used with care and never splashed around. Chuliá García includes too many comments, sometimes to explain puns, others to illuminate a particular reference in the text (in some cases adding unnecessary information), with the result that the translator becomes an uncomfortable presence in what otherwise is a perfectly acceptable version of O'Brien's novel.

Ráez Padilla, Juan. 2007. Los cuatro elementos y Seamus Heaney: de la cosmogonía helénica a la cosmopoética de The Spirit Level (1996). Jaén: Servicio de Publicaciones de la Universidad. ISBN: 978-84-8439-317-7.

Juan Ráez Padilla is a young scholar from the University of Jaén who has just published his Ph.D. dissertation on Seamus Heaney. His thesis comes in a nicely presented format which contains a CD with the full academic research and a book with a complete summary of his dissertation.

There are aspects in Seamus Heaney's work which have not been studied in detail, Ráez Padilla claims, particularly the symbology of the four natural elements: earth, water, air and fire. The aim of the present study is the analysis of those symbols in Heaney's poems, especially those contained in The Spirit Level (1996), where the force of nature plays an essential role. In Heaney's work there is a balance between the two types of opposing forces represented by the four elements, they engender violence and life at the same time. Ráez Padilla's study is an attempt to consider these elements in full in relation to the poet's writing.

In the first chapter Ráez Padilla goes back to the Pre-Socratic theorisation of the four elements (Thales of Miletus or Empedocles of Acragas). He traces the evolution of this theory along history and how it developed into a literary framework.

In the second chapter he deals with the different interpretations of Heaney's oeuvre. Curiously enough, Heaney's poetry has normally been theorised in terms of its earthly quality in his first period (rooted in Northern Irish history and culture), and its airy characteristics in a second stage, in which the poet searches for freedom and cuts himself from former ties. According to Ráez Padilla, the assignation of the "airy phase" for Seamus Heaney's poetry is inaccurate. Critics have not agreed on the precise point of transition between the two periods. Earth, furthermore, continues to be a leitmotiv in this second period. For the Spanish scholar reading Heaney's poetry in binary terms is not right and instead he proposes an interpretation in complementary terms, earth and air. The Irish poet's work would move in the space created by this tension.

In the third chapter Ráez Padilla proceeds on an informative journey through the way the four elements have been interpreted in literary criticism, including recent theories such as gender studies. He also offers a new deliberation based on a global perspective. In the final chapter of his dissertation, he applies this frame of reference to the study of The Spirit Level. Four approaches are employed to study the poems: ambivalence of the symbols, dialectic interrelationships between them, movement and 
combination. Emphasis is made on those aspects where Heaney's poetics remain apart from traditional symbology and which represent his search for balance.

In his conclusions Ráez Padilla defines the terms of the discussion and asserts that PreSocratic spiritualism pervades over Heaney's work: opposing principles are reconciled and spirit and body are frequently fused. "It is worth noting that, bearing in mind this hierarchy, the poetry of Seamus Heaney would diverge from the masculinity (air and fire) of the dominant symbolic discourse (reason, spirituality, light, warmth,...) in favour of the inspirational feminity of intuition, corporeality, coldness, darkness" (167). Contrary to the critical response to The Spirit Level, where an airy vision is preferred, Ráez Padilla considers the downwards movements in this book (the symbolic complex of Janus, he writes, two sides of the same coin) as an opposite force to the "etherealisation" in his poetry.

Politics are not wholly ignored despite such abstract theorisation of the elements. The interaction between air and earth, in fact, reveals Heaney's indeterminacy and acknowledged confusion on the role of the poet in society. Uncertainty in Heaney, says Ráez Padilla, must not be understood in a negative sense but as a legitimate emotional response. It could not be otherwise, he adds, in a poet subject to such antagonistic pressures (England/Ireland, Catholicism/Protestantism, social ethics/poetic ethics, etc.). Symbols are used in his poetry to represent his own personal complex universe and at the same time they represent a temporary release from oppressive systems of thought.

Ramón, Marta. 2007. A Provisional Dictator. James Stephens and the Fenian Movement. Dublin: University College Dublin Press. ISBN: 978-1-904558-64-4.

A Provisional Dictator is a chronicle of the history of Ireland after Daniel O'Connell's Catholic Association, a period that covers roughly the first and second decades of the second half of the $19^{\text {th }}$ century. The book is also a political biography insofar as the author focuses on the person of James Stephens, head of the Irish Republican Brotherhood, a secret society created in March 1858 destined to prepare the ground for a rebellion against England with the help of the Irish exiles in America. Finally, Marta Ramón's study is a revision and in many cases a correction of previous approaches to Stephens's figure. According to the author, Stephens's political thinking and his personal traits have only been described partially or without taking into account a comprehensive scholarly research. Ramón aims to provide an all-inclusive assessment of Stephens's revolutionary career, and consequently begins her account with Stephens's participation in the Young Ireland's 1848 insurrection.

The Young Irelanders were a new generation of nationalist leaders who seceded from O'Connell's Repeal Association for want of a more direct form of action against the colonial power. Starting from that point, Ramón dives into the murky waters of Irish Nationalist politics of those years, giving in profuse detail the motives behind every secession, division and confrontation inside a movement torn by internal strife. Almost every new initiative was followed by the withdrawal of some members from the association with their former colleagues because they demanded more energetic measures against British laws. The history of the Irish expatriates at the other side of the Atlantic, the Fenian Brotherhood, had a similar record of division.

Ramón's range of vision is wide enough to consider the evolution of international conflicts (the French insurrection of 1848, The Crimean War, the American Civil War, etc.) as well as internal events (the Potato Famine) and their impact on the Irish revolutionaries, as they were always waiting for England's weakness in order to start their own armed confrontation. But at all times this extensive point of view is accompanied by a precise rendering of personal documents such as letters, diaries, newspaper articles or police reports. This enables the author to tread firmly on uncertain ground, as when she deals with Stephens's early years. "We now have reason to believe" the author states "that James Stephens was born out of wedlock late in July 1825" (25). The illegitimacy of his birth would help to understand some personal attributes of the future revolutionary leader, like his egotism, his intellectual ambition or his megalomania, as he felt the need to assert himself against a 
desolate origin.

In the narrative, for that is what any historical account finally is, even in a thoughtful and welldocumented book as this one, it is compelling for the reader to witness Stephens's escape to France after the failure of the Ballingarry skirmish in 1848, his impressions of Paris, his learning and progress in contact with foreign revolutionaries, and his return to Ireland in 1855. Stephens's arrest by the police on 11 November 1865 and his ensuing escape from Richmond Prison two weeks later conveys a substantial dose of emotion. I believe this combination of dramatic vigour and authoritative consultation of original documents is something to be praised.

Ramón is, in general, sympathetic to the main character although she keeps a wary eye on Stephens's decisions and is able to express doubt about his high ideals: "For over a year after his arrival in France he could not (would not?) find employment..." (50). Likewise the author's denunciation of unacceptable deeds is normally tempered by the necessary distance. When explaining Stephens's bullying tactics against his competitors when the rebels' newspaper The Irish People was launched in 1863, Ramón admits that "It is easy to perceive an uncomfortable flavour of proto-Fascism in Stephens's attitude" (144). And then she adds on the same page: "Still - leaving assassination aside - it is difficult to imagine a different set of tactics that could be employed by an illegal revolutionary organization in attempting to overthrow a government and neutralise opposition from its adversaries” (144). Ramón thus manages to keep herself on the thin line that divides the expression of judgements on the past and the professional, objective account of the historian.

The book is a great achievement as regards the strenuous work involved in the research of such facts as Stephens's visits to America and the complex map of circumstances that determined the nature of the Fenian movement in the United States, which is told with a faultless command. The final two chapters, devoted to Stephens's fall from power and to the vain rising of March 1867, when he no longer influenced the destinies of the Irish Republican Brotherhood, are completed with an appropriate account of the dethroned leader's final years.

\section{Villacañas, Beatriz. 2007. Literatura irlandesa. Madrid: Síntesis. ISBN: 978-84-975647-4-8.}

Beatriz Villacañas has written an easily readable and at the same time well-documented manual on Irish literature. Her starting points, stated in the introduction to the book, show that common sense has been the ruling principle of her task. Firstly, Irish literature must be studied independently from English literature (although at any time all kinds of connections between both must be made). Secondly, Irish literature, perhaps more than any literature in the world, must be contextualised: an understanding of the history of rebellion of a great part of the Irish people against a colonizing power must be paramount, but also the differentiated nature of two kinds of population groups, the Anglo-Irish and the Gaelic stock, as well as their religious differences. Finally, the approach to such a heterogeneous material must be at the same time general and specific, rigorous in the detailed account of each individual author but ample enough to take into account the historical circumstances of each period.

Considering that Villacañas's manual consists of 200 pages (glossary of useful terms, chronology and bibliography not included), it has to be said that the author passes the test with aplomb. Villacañas is likewise careful to explain that hers is a history of Irish literature written in English, although she does not forget the rich and suggestive corpus of epic and myth belonging to the island's Celtic past.

After a brief but illustrative section on the history of Ireland, in the second chapter the author puts into practice her method of analysis with the discussion of the Anglo-Irish writers of the colonial period: Lawrence Sterne, Jonathan Swift and Thomas Moore. Villacañas manages to offer a balanced account of each of the writers she deals with. Jonathan Swift, for instance, is presented as the first Anglo-Irish author to denounce the injustice of the colonial system, although he basically defended the rights of his own class.

The fact that the author includes excerpts from many of the writers under study together with their translation into Spanish, and fragments of selected criticism, reinforces the divulgative intention of the book. Terence Brown, Hugh Kenner, George Watson, Declan Kiberd, Robert 
Hughes and Inés Praga are quoted at large and then translated into Spanish. I interpret this as an example of Villacañas's honesty: an enterprise like writing the history of Irish literature cannot be accomplished without the assistance of fundamental names in Irish criticism.

The chapters proceed in chronological order without an alteration in the method already described: the first half of the nineteenth century and the beginning of the 'Big House' novel; the Victorian Gothic of Sheridan Le Fanu and Bram Stoker; the translations from Irish of James Clarence Mangan or the naturalist narratives of George Moore, just to mention a few names.

There is a whole chapter devoted to Wilde and Shaw, and another one on the Irish Literary Renaissance. The section on Wilde avoids hackneyed notions on the dramatist, dealing instead with Wilde's Irishness and his not always clearly-understood ethics.

Villacañas is equally sharp in her description of the founding of the Abbey Theatre and the contradictions that the movement led by Lady Gregory and W.B. Yeats fell into. For the cultivated Anglo-Irish literati, the urban Catholic middle-classes represented a dullness and vulgarity that they wanted to avoid at all costs, but those drab people had worked and fought all their lives for the independence of their country. As Villacañas remarks, "El Abbey fue el punto de desencuentro entre estas dos Irlandas" (66).

Many other aspects are similarly clarified in each chapter without a recourse to simplification. Synge, for example, forced the language in his plays into a perhaps abusive use of HibernoEnglish, but his was at the same time a true representation of the colourful language of the Irish people.

There is an efficient chapter on James Joyce, another one on literature after independence and a further section on contemporary literature. Here the authors are exposed briefly, as befits a period so rich in various literary forms. One would have liked the author of Literatura irlandesa to expand more on personal favourites like Bernard Mac Laverty or Medbh McGuckian, and to write a few lines on Aidan Higgins, but it is true that longer explanations or the inclusion of all writers of the last fifty years would have resulted in an altogether different book.

The two final chapters, dealing with the
Irish Diaspora and with a selection of poems translated and commented by the author offer an interesting supplement to the volume. These two last chapters, in fact, testify to the divulgative scope of the book despite its relatively few pages. Together with the unfortunately no longer available Diccionario cultural e histórico de Irlanda by Hurtley, Hughes, González Casademont, Praga and Aliaga (Barcelona: Ariel, 1996) Literatura irlandesa would be a volume to strongly recommend to those wishing to introduce themselves into Irish culture.

Villar-Argáiz, Pilar. 2007. Eavan Boland's Evolution as an Irish Woman Poet. An Outsider Within an Outsider's Culture. Lewiston: The Edwin Mellen Press. ISBN: 978-0-7734-5383-8.

Admirers of Eavan Boland's poetry will be grateful to Pilar Villar-Argáiz because this lecturer from the University of Granada has written a valuable examination of the work of one of Ireland's finest women poets. Pilar VillarArgáiz's study is interesting because she considers Boland's poetry under a dual feminist and postcolonial framework. She therefore starts from the assumption of Irish literature as a postcolonial cultural production, but complements her analysis with a feminist approach.

Women in Ireland, it is stated in the book, have been doubly colonized, both by imperialism from abroad and by a restrictive nationalism at home. Accordingly, the theories of Frantz Fanon and Albert Memmi, who have written on the stages of oppression, protest and liberation of the postcolonial writer, on the one hand, and the three phases of women's writing (feminine, feminist and female) articulated by Elaine Showalter, on the other, are employed to assess the different periods of Boland's evolution as a woman poet.

After the introductory remarks, Pilar VillarArgáiz addresses the issue of how Eavan Boland began her literary career. In her two first volumes of poetry (Eavan Boland Poetry, 1963, and New Territory, 1967) the writer is presented as an uncertain individual wanting to be accepted by the poetic community. This was her feminine or assimilationist phase, where she concealed the woman in her and remained attached to her 
(male) literary forefathers. Yeats's great influence on the fledging poet is dutifully considered here. It is also explained that Boland maintained in her work a detached position from the poetic figures she represented.

Villar-Argáiz analyses different poems of this first period and discovers in them affinities with the struggling woman poet trying to accommodate herself to pre-existing modes. Here we find an exercise in blending theory and practice which will be repeated in subsequent chapters and which is one of the assets of this volume. Villar-Argáiz has not tried to force her subject of study, Boland's poetry, into the disciplined methodological moulds she has set for the task. At the beginning of the next chapter, in which she discusses Boland's second "feminist" phase (or the "cultural nationalist" one in terms of Fannon and Memmi), VillarArgáiz chooses In Her Own Image (1980) as a representative book of this period, and she states that a previous volume of poems, The War Horse (1975) will be used to comment on Boland's third phase, thus disturbing the logic of a chronological sequence. But here Villar-Argáiz is doing nothing but admitting that literature is not one of the exact sciences: "Although Boland's evolution as a poet underlies a process of increasing poetic maturity (a process of initial imitation, intermediate protest, and final artistic autonomy), the departure from the inherited poetic tradition is not an easy step to take, and Boland, on her journey towards attaining artistic decolonisation, shows backward and forward movements" (99).

It is very illustrative to turn regularly to the appendix where an interview with the author is recorded (an unusual and gratifying surprise in a book of this kind), where Boland for instance comments upon her beginnings as a writer: "It's hard to get to those poems in my mind. I haven't opened any of them in twenty or thirty years. I was a teenager, and an immature one at that. I think real feeling went into them, but no craft" (398).

Contrary to those initial texts, In Her Own Image is defined by Villar-Argáiz as a groundbreaking volume in Boland's career, as she expressed her womanhood against the canon of traditional Irish poetry. She angrily attacked those aspects of patriarchal society that she considered damaging for her reality as a woman. In this second step of her development Boland advocated her right to be in control of the subjects of the poem. Villar-Argáiz revealingly explores how Boland reclaimed taboo areas of female experience and connects the new perspective that the poet found in her inside journey with Boland's reading at the time of Adrienne Rich's work. Poetry and theory are fused again in a densely woven discourse and all aspects of the poems in In Her Own Image are discussed, like the alienating linguistic techniques that Boland took hold of in order to denounce the corruption exerted by malecentered myths (obsessive depiction of special imagery, avoidance of possessive constructions in the first person, etc.). Boland entered with this book in disturbing territories, like alternative visions of child-bearing and maternal love, although she did not escape an essentialist view of women in her new assertion of the self.

The final chapter of the volume discovers Boland in her mature phase, an artist who has reached an autonomous self-expression, free from the dependence of opposing terms and fully independent of the literary mainstream. The poems analysed here cover a wide spectrum, from The War Horse (1975) to The Journey (1986), In a Time of Violence (1994), Outside History (1990), The Lost Land (1998) and Code (2001). Villar-Argáiz describes Boland giving voice to her own experiences as a woman, as a citizen and as a poet, that is, avoiding any attempt at constructing a poetic identity in essentialist terms. We are, in fact, in what Showalter denominates a "deliberate female aesthetic" or Fanon and Memmi a "liberating" writing.

This chapter, which is complexly drawn and where the author has delved more fully into her subject, is divided in four sections: the first one focuses on Boland's main source of her poetic creativity: her life as a suburban married mother. The second section is dedicated to Boland's deconstruction of poetic identity. Here her poetry will be analyzed according to Mikhail Bakhtin's theory of hybridisation, again stepping aside from a constrained theoretical imposition, just as in the previous chapter Villar-Argáiz turned to various feminist critics such as Cixous and Irigaray. The third section considers Boland's 
attempt to give voice to those lived experiences that lie unrecorded by nationalist historical accounts. Finally, in the fourth section, which explores Boland's exile in the United States, the poet is presented psychologically detached from dominant nationalist discourses. As VillarArgáiz writes, her most recent poems move towards the possibility of conceiving identity in terms of fluidity and boundary crossing. 